\title{
Sexual maturation and the adrenal glands
}

\author{
H. M. A. Meijs-Roelofs and J. Moll \\ Department of Anatomy, Erasmus University, Rotterdam, The Netherlands
}

It is a definite possibility that organs which are primarily elements of functional systems other than the reproductive system are involved in sexual maturation. The adrenal glands are attractive candidates for such a role in sexual maturation: they are capable of producing androgens, oestrogens and progesterone, not only in the adult, but also in the prepubertal animal. This points to the adrenal cortex as source of hormonal material that may be directly involved in sexual maturation. Studies in which adrenalectomy, followed by reimplantation of the adrenal glands, was performed, provide proof that medullary degeneration does not influence sexual maturation (Gorski \& Lawton, 1972, 1973).

We will review here the main lines of available evidence on involvement of the adrenal glands in sexual maturation. Emphasis will be on the female rat which has been studied most extensively. The following topics will be discussed. (1) Hormone production by the adrenal glands during sexual maturation. This background information seems important if a possible role of the adrenal glands in sexual maturation is considered. (2) Interactions that have been observed between adrenal gland function and the reproductive system in the prepubertal animal. Although existence of such interactions does not necessarily give (direct) proof of adrenal involvement in sexual maturation, it does perhaps indicate how the adrenal glands may contribute to sexual maturation. (3) Experimental alteration of adrenal function and sexual maturation: under this heading we will discuss the various parameters of sexual maturation that have been studied after experimental manipulation of adrenal function, in which the approach has been largely restricted to adrenalectomy. (4) Finally, we will discuss whether, when established, an influence of the adrenal glands on sexual maturation must be attributed to a specific interaction of the adrenal glands with the hypothalamo-pituitary-ovarian system or whether it is due to more general effects of adrenal function on bodily development. It is well-known that the stage of bodily development reached is a decisive factor in sexual maturation.

\section{Hormone production of the adrenal glands during sexual maturation}

Corticosterone secretion is already present in the newborn rat, as is a short-lasting, neonatal pituitaryadrenal responsiveness to environmental stimuli (Allen \& Kendall, 1967; Koch, 1969; Levine, 1970). This period is followed by one of diminished activity, after which stress responsiveness of plasma corticosterone develops again at the age of 15 days and more (Allen \& Kendall, 1967; Levine, 1970). An adult-like level of function is then reached at about weaning age (see Goldman, Winget, Hollingshead \& Levine, 1973). This time pattern of adrenal activity seems to parallel adrenal responsiveness to adrenocorticotrophic hormone (ACTH) (Cote \& Yasumura, 1975). A circadian rhythm of corticosterone secretion, with higher evening than noon values, develops at about 23 days of age (Ramaley, 1972).

Production of oestrogens or, using a more cautious term, oestrogen-like substances by the prepubertal adrenal cortex should be considered. The results so far obtained by radioimmunoassay techniques are conflicting, probably due-at least in part-to the use of different antibodies which react differently with different steroidal materials. Thus, several authors found a mainly adrenal origin of the materials measured (Weisz \& Gunsalus, 1973; Morera, Audi \& Saez, 1974; Ojeda, Kalra \& McCann, 1975), with the materials reaching considerable blood concentrations. In our laboratory, the comparatively low concentrations of circulating oestrogens were found to be of purely ovarian origin (Meijs-Roelofs, Uilenbroek, de Jong \& Welschen, 1973). In line with these results seem our recent findings that adrenalectomy in the immature rat has no effect on uterine weight (MeijsRoelofs \& Kramer, 1977), indicating the absence of biological activity of the adrenal products, at least at the uterine level. Also, Macfariand \& Mann (1977) found, in general, no effect on uterine 
weight after adrenalectomy. Recently, however, Gorski-Firlit (1976) reported increased oestradiol levels in a study of short-term effects of laparotomy stress and ovariectomy, suggesting adrenal oestrogen secretion in certain circumstances of stress and at certain ages. Clearly, no final conclusion can be reached for the moment on the nature of adrenal oestrogen-like products or the situations and age periods during which they may be secreted.

With regard to progesterone there seems to be no doubt about the adrenal production of this steroid in the immature rat. However, no definite answer has been reached here concerning the question whether the adrenal glands are the major source of progesterone or whether the ovaries are the main contributors to the plasma progesterone levels. Adrenal progesterone has been reported to be secreted in a circadian rhythm; progesterone levels were found to be quite high 11 days after ovariectomy on Day 22 of age (Ramaley \& Bartosik, 1974) while low levels of progesterone, and loss of the rhythm, were reported 7 days after adrenalectomy on Day 22 (Ramaley \& Bartosik, 1975a). These data are in favour of the adrenal glands being the major source of prepubertal progesterone production. In agreement herewith, Macfarland \& Mann (1977) reported undetectable progesterone levels by Day 25 following adrenalectomy on Day 21. In contrast, Meijs-Roelofs, de Greef \& Uilenbroek (1975) reported a greater decrease in progesterone level at 1 and 2 days after ovariectomy than after adrenalectomy, both operations being performed on Day 18. These data indicate that the ovaries are the main source of progesterone. Since, in these studies, the sum of the losses after either operation was higher than the amount of progesterone present in control rats, ovarian-adrenal interactions in progesterone production cannot be excluded. Possibly, the existence of such interactions as well as differences in experimental design of the studies account for the apparent discrepancies in conclusions about the origin of plasma progesterone in immature animals.

Work on man has emphasized a possible role of adrenal androgens in sexual maturation. The blood level of androstenedione and of dihydroepiandrosterone has been found to rise before the start of hormonal changes known to be related to onset of puberty (Sizonenko \& Paunier, 1975; Collu \& Ducharme, 1975; Ducharme et al., 1976).

\section{Interactions between the adrenal glands and the reproductive system in the pubertal animal}

At various levels the interactions and parallel functional development of the adrenal glands and the reproductive system have been reported. For example, the circadian rhythm of plasma progesterone, mentioned above, only develops after establishment of the corticosterone rhythm (Ramaley \& Bartosik, 1974, 1975b), suggesting that the corticosterone rhythm induces the adrenal progesterone rhythm. Adrenal progesterone secretion may be stimulated by ACTH treatment in the immature rat (Macfarland \& Mann, 1977) as in the adult rat (Resko, 1969; Fajer, Holzbauer \& Newport, 1971; Piva, Gagliano, Motta \& Martini, 1973). Endogenous ACTH secretion takes place following a circadian rhythm, which persists after adrenalectomy (see Gorski-Firlit, 1976), indicating a central nervous origin of this rhythm. Bartosik, Szarowski \& Watson (1971) described a stimulating influence of PMSG-stimulated ovarian tissue on the concentration of progesterone in adrenal vein blood, suggesting that the functional condition of the gonads may influence adrenal progesterone production. A possible interaction between ovarian and adrenal progesterone production has already been mentioned.

Characteristic changes in basal as well as stress-induced patterns of corticosterone secretion related to the first ovulation, occurring spontaneously or induced by PMSG, have been reported (Ramaley, 1972; Ramaley \& Bunn, 1973; Ramaley \& Olson, 1974), and they suggest that the onset of ovulatory activity stimulates adrenal function. These changes in adrenal function related to onset of ovulatory activity were suppressed but not eliminated by castration (Ramaley, 1972).

More experiments relating corticoid secretion-reproductive system interactions have been reported. Stress may cause, in addition to effects on corticoid secretion, a delay in onset of ovulatory cyclicity in mice (Paris \& Ramaley, 1973, 1974). The effects of adrenalectomy on gonadotrophin levels have also been described. Döhler, van zur Mühlen \& Döhler (1976) reported increased serum levels of both FSH and LH following adrenalectomy. However, Rabii \& Ganong (1976) found no greater increase in LH levels after combined ovariectomy and adrenalectomy than after ovariectomy 
alone. Recent findings in our laboratory (Meijs-Roelofs \& Kramer, 1977) indicate that at younger ages adrenalectomy may even cause decreased FSH secretion, whereas after Day 15 an increased FSH level was sometimes found. However, such an increase in FSH level was only present in those adrenalectomized rats that showed retarded body weight gain, i.e. in rats with a bodily development more appropriate to a younger age at which the observed post-adrenalectomy FSH levels would be within the normal range. Also, LH levels after adrenalectomy were generally not different from those in sham-operated and intact controls but high individual variations were encountered in all groups (unpublished observations). It may be concluded that no effects of adrenalectomy on FSH (gonadotrophins) were present when not only calendar age but also body weight was used as a parameter.

A decrease in prolactin level after adrenalectomy in immature rats has been reported (Gelato, Dibbet, Marshall, Meites \& Wuttke, 1976).

\section{Experimental alteration of adrenal function and sexual maturation}

An obvious parameter in studies in adrenal influences on sexual maturation is the age at which vaginal opening and first ovulation occur (see Ramaley, 1974). A delay in both phenomena following adrenalectomy has been reported, in part accompanied by an increased time interval between vaginal opening and first ovulation (Ramaley \& Bunn, 1972; Gorski \& Lawton, 1972, 1973; Ramaley, 1973; GorskiFirlit \& Lawton, 1974; Ramaley \& Bartosik, 1975b; Ramaley, 1976a, b; Macfarland \& Mann, 1977). Recent observations in our laboratory, however, indicate that the effects of adrenalectomy on vaginal opening and first ovulation, if present at all, are no longer found when not only age but also body weight is used as the indicator of stage of development (Meijs-Roelofs \& Kramer, 1977; Table 1). The data of Macfarland \& Mann (1977) point in the same direction: after adrenalectomy a delay in age of vaginal opening was found, together with a diminished gain in body weight.

Table 1. Effect of adrenalectomy on age and body weight (mean \pm s.e.m.) at first oestrus in rats (from Meijs-Roelofs \& Kramer, 1977)

\begin{tabular}{|c|c|c|c|c|}
\hline \multirow{2}{*}{$\begin{array}{l}\text { Age at operation } \\
\text { (days) }\end{array}$} & \multirow[b]{2}{*}{ Exp. group } & \multirow[b]{2}{*}{ No. of rats } & \multicolumn{2}{|c|}{ First oestrus* } \\
\hline & & & Age (days) & Body weight (g) \\
\hline 20 & $\left\{\begin{array}{l}\text { Intact } \\
\text { Sham-operated } \\
\text { Adrenalectomized }\end{array}\right.$ & $\begin{array}{r}9 \\
9 \\
10\end{array}$ & $\begin{array}{l}39.4 \pm 0.2 \\
40.4 \pm 0.5 \\
42.5 \pm 0.9 \dagger\end{array}$ & $\begin{array}{l}94.9 \pm 1.8 \\
93.4 \pm 1.2 \\
92.4 \pm 1.8\end{array}$ \\
\hline 25 & $\left\{\begin{array}{l}\text { Intact } \\
\text { Sham-operated } \\
\text { Adrenalectomized }\end{array}\right.$ & $\begin{array}{l}15 \\
15 \\
16\end{array}$ & $\begin{array}{l}38.8 \pm 0.5 \\
39 \cdot 5 \pm 0.4 \\
41.4 \pm 0.5 \ddagger\end{array}$ & $\begin{array}{l}93 \cdot 8 \pm 1 \cdot 2 \\
92 \cdot 6 \pm 1 \cdot 6 \\
95 \cdot 0 \pm 1 \cdot 2\end{array}$ \\
\hline 30 & $\left\{\begin{array}{l}\text { Intact } \\
\text { Sham } \\
\text { Adrenalectomized }\end{array}\right.$ & $\begin{array}{r}10 \\
6 \\
10\end{array}$ & $\begin{array}{l}39 \cdot 1 \pm 0.6 \\
40 \cdot 0 \pm 0 \cdot 6 \\
40 \cdot 7 \pm 1 \cdot 2\end{array}$ & $\begin{array}{l}91.9 \pm 2.4 \\
93.0 \pm 2.0 \\
90.7 \pm 2.7\end{array}$ \\
\hline 35 & $\left\{\begin{array}{l}\text { Intact } \\
\text { Sham-operated } \\
\text { Adrenalectomized }\end{array}\right.$ & $\begin{array}{l}12 \\
11 \\
14\end{array}$ & $\begin{array}{l}37 \cdot 3 \pm 0.3 \\
37 \cdot 7 \pm 0.6 \\
39 \cdot 1 \pm 1 \cdot 1\end{array}$ & $\begin{array}{l}90 \cdot 3 \pm 1.5 \\
90 \cdot 3 \pm 1.9 \\
87.7 \pm 2.2\end{array}$ \\
\hline
\end{tabular}

* Day of first vaginal oestrous smear, followed by day of metoestrous smear.

$\uparrow$ Significantly different compared with value of intact animals, $P<0.05$.

$\ddagger$ Significantly different compared with values for intact and sham-operated animals, $P<0 \cdot 01$.

The process of ovulation itself might show alterations in adrenalectomized rats: triggering of the ovulatory gonadotrophin release by adrenal progesterone has been suggested for the adult rat (Feder, Brown-Grant \& Corker, 1971; Lawton, 1972; Mann \& Barraclough, 1973; Piva et al., 1973), and effects of adrenalectomy on follicular development and number of ova shed were reported by Peppler \& Jacobs (1976). However, Mann, Korowitz \& Barraclough (1975) found normal full ovulation in acutely and chronically adrenalectomized rats and no overall effect on the ovulatory $\mathrm{LH}$ release, apart from a change in time pattern of release. Therefore, in the adult rat any effects of adrenalectomy seem only marginal. 
In the pubertal rat the effects of (chronic) adrenalectomy on the number of ova shed are not convincing: normal numbers of ova after adrenalectomy were reported by Gorski \& Lawton (1973) and Macfarland \& Mann (1977), whereas ovulation of fewer ova was reported by Gorski-Firlit \& Lawton (1974), even when no delay in age of vaginal opening was found. Data on the acute effects of adrenalectomy on spontaneous first ovulation are, so far as we know, lacking. We have recently studied such effects by performing adrenalectomy between 08:00 and 10:00 h on the morning of first pro-oestrus and counting the ova the next morning between 10:00 and 11:00 h. It was found that the number of ova shed was within the normal range (7-12 ova) for all experimental groups, being $8.4 \pm 0.3(\mathrm{~N}=10)$ in adrenalectomized rats, $9 \cdot 8 \pm 0.4(\mathrm{~N}=8)$ ova in sham-operated and $9 \cdot 5 \pm 0.5$ $(\mathrm{N}=11)$ ova in intact rats. The difference in the number of ova shed by adrenalectomized and shamoperated rats was significant $(P \leqslant 0.05)$.

\section{Specificity of adrenal effects on sexual maturation}

The crucial issue in experiments aimed at exploring a possible contribution of the adrenal glands in sexual maturation can be formulated in two questions. Is parallel functional development and functional interaction between the adrenal glands and the reproductive system a prerequisite for normal sexual maturation? The second question arises, when the first one is answered affirmatively. Can the contribution of the adrenal glands to sexual maturation be called a specific one? As discussed, secretion of adrenocortical hormones has been thought to be of importance for sexual maturation. Especially, changes in rhythmicity of adrenal function have been thought to be related to the progress of sexual maturation (see Ramaley, 1974). Concerning the adrenocortical factors involved, Ramaley (1976a) reported that, after adrenalectomy, replacement with corticosterone only was able to correct a delay of vaginal opening and first ovulation. This suggests that adrenal sex steroids do not cause the delaying effect of adrenalectomy. In a later study it was demonstrated (Ramaley, 1976b) that it was not the daily rhythm of corticosterone but rather the presence of a certain level of this hormone which was essential for the normal timing of pubertal events. Thus the adrenal rhythmicity seems a coincidence with, rather than a cause of, pubertal events, whereas the non-existence of functionally important adrenal sex steroids seems to be demonstrated by the lack of definite effects of adrenalectomy on uterine weight and on gonadotrophin secretion (see above).

It is furthermore of importance that the adrenal effects on age at vaginal opening and first ovulation are moderate and are, as discussed, no longer present when not only age but also body weight is used as an index of general somatic maturity. The effects of adrenalectomy on the numbers of ova shed do not seem to be conclusive.

The adrenal cortex does not constitute, in our opinion, an essential element in the maturation of the reproductive system. However, indirectly, by way of its influence on general metabolic processes the adrenal cortex is important for sexual maturation, more specifically for reaching at a normal age the stage of bodily development that seems crucial for onset of ovulatory activity.

\section{References}

Allen, C. \& Kendall, J.W. (1967) Maturation of the circadian rhythm of plasma corticosterone in the rat. Endocrinology 80, 926-930.

Bartosik, D., Szarowski, D.H. \& Watson, D.J. (1971) Influence of functioning ovarian tissue on the secretion of progesterone by the adrenal glands of female rats. Endocrinology 88, 1425-1428.

Collu, R. \& Ducharme, J.R. (1975) Role of adrenal steroids in the regulation of gonadotropin secretion at puberty. J. Steroid Biochem. 6, 869-872.

Cote, T.E. \& YAsumura, S. (1975) Effect of ACTH and histamine stress on serum corticosterone and adrenal cyclic AMP levels in immature rats. Endocrinology 96, 1044-1047.
DöhleR, K-D., von zƯR MÜhlen, A. \& DöhleR, U. (1976) Estrogen-gonadotropin interaction in postnatal female rats and the induction of an ovulatory sterility by treatment with an estrogen-antagonist. Annls Biol. anim. Biochim. Biophys. 16, 363-372.

Ducharme, J.R., Forest, M.G., de Peretti, E., Sempé, M., Collu, R. \& Bertrand, J. (1976) Plasma adrenal and gonadal sex steroids in human pubertal development. J. clin. Endocr. Metab. 42, $468-476$.

Fajer, A.B., Holzbauer, M. \& Newport, H.M. (1971) The contribution of the adrenal gland to the total amount of progesterone produced in the female rat. J. Physiol., Lond. 214, 115-126. 
Feder, H.H., Brown-Grant, K. \& Corker, C.S. (1971) Preovulatory progesterone, the adrenal cortex and the "critical period" for luteinizing hormone release in rats. $J$. Endocr. 50, 29-39.

Gelato, M., Dibbet, J., Marshall, S., Meites, J. \& Wuttke, W. (1976) Prolactin-adrenal interactions in the immature female rat. Annls Biol. anim. Biochim. Biophys. 16, 395-397.

Goldman, L., Winget, C., Hollingshead, G.W. \& LEVINE, S. (1973) Postweaning development of negative feedback in the pituitary-adrenal system of the rat. Neuroendocrinology 12, 199-211.

Gorski, M.E. \& Lawton, I.E. (1972) Timing of the prepuberal adrenal-ovarian interaction in the rat. Biol. Reprod. 7, 112.

Gorski, M.E. \& LAwTON, I.E. (1973) Adrenal involvement in determining the time of onset of puberty in the rat. Endocrinology 93, 1232-1234.

GoRSKI-FIRLIT, M. (1976) The adrenal gland and puberty. In Sexual Maturity. Physiological and Clinical Parameters, pp. 85-101. Eds E.S.E. Hafez \& J.J. Peluso. Ann Arbor Science, Publishers Inc., Ann Arbor, Michigan.

GORSKI-FIRLIT, M. \& LAwTON, I.E. (1974) The timing of the adrenal ovarian interaction period in the prepuberal rat. Biol. Reprod. 11, 413-420.

Koch, B. (1969) Fraction libre de la corticostérone plasmatique et résponse hypophyso-surrénalienne au stress durant la période post-natale chez le rat. Horm. Metab. Res. 1, 301-308.

LAWTON, I.E. (1972) Facilitatory feedback effects of adrenal and ovarian hormones on LH secretion. Endocrinology 90, 575-579.

Levine, S. (1970) The pituitary-adrenal system and the developing brain. In Progress in Brain Research, Vol. 32, pp. 79-85. Eds D. De Wied \& J.A.W.M. Weijnen. Elsevier, Amsterdam.

Macfarland, L.A. \& ManN, D.R. (1977) The inhibitory effects of ACTH and adrenalectomy on reproductive maturation in female rats. Biol. Reprod. 16, 306-314.

ManN, D.R. \& Barraclough, C.A. (1973) Role of estrogen and progesterone in facilitating $\mathrm{LH}$ release in 4-day cyclic rats. Endocrinology 93, 694-699.

ManN, D.R., Korowitz, C.D. \& Barraclough, C.A. (1975) Adrenal gland involvement in synchronizing the preovulatory release of LH in rats. Proc. Soc. exp. Biol. Med. 150, 115-120.

MeIJs-Roelofs, H.M.A. \& Kramer, P. (1977) Effects of adrenalectomy on release of follicle-stimulating hormone and on the onset of puberty in female rats. J. Endocr. 75, 419-426.

Meiss-Roelofs, H.M.A., Uilenbroek, J.Th.J., DE JONG, F.H. \& WELSCHEN, R. (1973) Plasma oestradiol$17 \beta$ and its relationship to serum follicle-stimulating hormone in immature female rats. $J$. Endocr. 59, 295-304.

Meijs-Roelofs, H.M.A., de Greef, W.J. \& Uilenbroek, J.TH.J. (1975) Plasma progesterone and its relationship to serum gonadotrophins in immature female rats. J. Endocr. 64, 329-336.

Morera, A.-M., Audi, L. \& Saez, J.M. (1974) Augmentation de la progestérone et pic de composés oestrogène-immunoréactifs dans le plasma des rats impubères. C. r. hebd. Séanc. Acad. Sci., Paris 579, 73-76.

Ojeda, S.R., KalRa, P.S. \& McCann, S.M. (1975) Further studies on the maturation of the estrogen negative feedback on gonadotropin release in the female rat. Neuroendocrinology 18, 242-255.

Paris, A.L. \& Ramaley, J.A. (1973) Effects of shortterm stress upon fertility. I. Before puberty. Fert. Steril. 24, 546-552.

Paris, A.L. \& Ramaley, J.A. (1974) Adrenal gonadal relations and fertility: the effects of repeated stress upon the adrenal rhythm. Neuroendocrinology 15, 126-136.

PepPleR, R.D. \& JACoBs, J.J. (1976) The effect of adrenalectomy on ovulation and follicular development in the rat. Biol. Reprod. 15, 173-178.

Piva, F., Gagliano, P., Motta, M. \& Martini, L. (1973) Adrenal progesterone: factors controlling its secretion. Endocrinology 93, 1178-1184.

RABII, J. \& GANONG, W.F. (1976) Response of plasma "estradiol" and plasma LH to ovariectomy, ovariectomy plus adrenalectomy, and estrogen injection at various ages. Neuroendocrinology 20, 270-281.

Ramaley, J.A. (1972) Changes in daily serum corticosterone values in maturing male and female rats. Steroids 20, 185-197.

RAmaley, J.A. (1973) Role of the adrenal in PMSinduced ovulation before puberty: effect of adrenalectomy. Endocrinology 92, 881-887.

RAmaley, J.A. (1974) Mini-review: adrenal-gonadal interactions at puberty. Life Sciences 14, 1623-1633.

RAmaley, J.A. (1976a) The role of corticosterone rhythmicity in puberty. Biol. Reprod. 14, 151-156.

RAMALEY, J.A. (1976b) The role of adrenal rhythmicity in puberty: effects of intermittent steroid replacement. Biol. Reprod. 15, 396-401.

Ramaley, J.A. \& Bartosik, D. (1974) Rhythms of progesterone and corticosterone after PMS-induced puberty: effects of ovariectomy. Endocrinology 95, 1719-1725

Ramaley, J.A. \& Bartosik, D. (1975a) Precocious puberty: the effect of adrenalectomy on PMSinduced ovulation and progesterone secretion. Endocrinology 96, 269-274.

RAMALEY, J.A. \& BARTOSIK, D. (1975b) Effect of adrenalectomy on light-induced precocious puberty in rats. Biol. Reprod. 13, 347-352.

RAMALEY, J.A. \& BUNN, E.L. (1972) Seasonal variations in the onset of puberty in rats. Endocrinology 91, 611-613.

RamaleY, J.A. \& BunN, E.L. (1973) Adrenal function in rats given PMS before puberty: serum corticosterone values. Neuroendocrinology 12, 257-271.

Ramaley, J.A. \& Olson, J. (1974) Adrenal function in rats given PMS before puberty: response to ether stress. Neuroendocrinology 14, 1-13.

RESKO, J.A. (1969) Endocrine control of adrenal progesterone secretion in the ovariectomized rat. Science, N.Y. 164, 70-71.

Sizonenko, P.C. \& PaUnier, L. (1975) Hormonal changes in puberty. III. Correlation of plasma dehydroepiandrosterone, testosterone, FSH and LH with stages of puberty and bone age in normal 
boys and girls and in patients with Addison's disease or hypogonadism or with premature or later adrenarche. J. clin. Endocr. Metab. 41, 894-904.
Weisz, J. \& Gunsarus, P. (1973) Estrogen levels in immature fomale rats: true or spurious-ovarian or adrenal. Endocrinology 93, $1057-1065$. 